\title{
Analisis Kemampuan Pemahaman Konsep Matematis Mahasiswa
}

\author{
Diyah Hoiriyah* \\ Email: diyah@iain-padangsidimpuan.ac.id \\ Fakultas Tarbiyah dan Ilmu Keguruan IAIN Padangsidimpuan
}

\begin{abstract}
This study aims to analyze the ability to understand the mathematical concepts of PGMI students in the subject of low grade mathematics studies in MI / SD. The main data form in this study is the work of students in answering written test questions about fractions.

The ability to understand the mathematical concepts of PGMI-1 students is still relatively low, based on the results of the analysis of the results of student answers to tests of the ability to understand the concept of fractions. Of the 3 test questions given by researchers to PGMI-1 students, there are still many students who have not been able to answer the questions correctly that is equal to $62.75 \%$ so that the answers students give illustrate that understanding the mathematical concepts possessed by students is still low.
\end{abstract}

Keywords: ability analysis, understanding mathematical concepts, mathematical concepts, fractions, mathematics

\begin{abstract}
Abstrak
Penelitian ini bertujuan untuk menganalisis kemampuan pemahaman konsep matematis mahasiswa PGMI pada mata kuliah kajian matematika kelas rendah MI/SD. Bentuk data utama dalam penelitian ini adalah hasil pekerjaan mahasiswa dalam menjawab soal tes uraian tertulis mengenai bilangan pecahan.

Kemampuan pemahaman konsep matematis mahasiswa PGMI-1 masih tergolong rendah, berdasarkan hasil analisis terhadap hasil jawaban mahasiswa pada tes kemampuan pemahaman konsep bilangan pecahan. Dari 3 soal tes yang diberikan peneliti kepada mahasiswa PGMI-1, masih banyak mahasiswa yang belum dapat menjawab pertanyaan dengan benar yaitu sebesar 62,75\% sehingga jawaban-jawaban yang mahasiswa berikan menggambarkan bahwa pemahaman konsep matematis yang dimiliki oleh mahasiswa masih rendah.
\end{abstract}

Kata Kunci: analisis kemampuan, pemahaman konsep matematis, konsep matematika, bilangan pecahan, matematika

* Correspondence:

Email: diyah@iain-padangsidimpuan.ac.id 


\section{A. PENDAHULUAN}

Matematika sebagai ilmu dasar mempunyai peranan yang sangat penting dalam ilmu pengetahuan dan teknologi. Oleh sebab itu, dalam dunia pendidikan matematika dipelajari oleh semua siswa mulai dari tingkat sekolah dasar sampai pada perguruan tinggi. Pentingnya matemetika ini mengharuskan untuk setiap orang yang mengecap dunia pendidikan memiliki pemahaman akan konsep matematika itu.

Istilah pemahaman berasal dari akar kata paham, yang menurut Kamus Besar Bahasa Indonesia diartikan sebagai pengetahuan banyak, pendapat, aliran, mengerti benar. ${ }^{1}$ Secara istilah pemahaman itu diartikan sebagai proses, cara, perbuatan memahami atau memahamkan. Dengan demikian pemahaman dapat diartikan sebagai kemampuan untuk memahami sesuatu dan menerjemahkan dari suatu bentuk ke bentuk lain setelah sesuatu itu diketahui.

Untuk memahami sesuatu, menurut Bloom, siswa harus melakukan lima tahapan berikut: 1) receiving (menerima); 2) responding (membandingbandingkan); 3) Valuing (menilai); 4) Organizing (diatur); dan 5) characterization (penataan nilai). ${ }^{2}$ Hal senada juga di kemukakan oleh Sumarno bahwa untuk memahami suatu objek secara mendalam, sedikitnya seseorang harus mengetahui lima aspek penting, yaitu: 1) objek itu sendiri; 2) relasinya dengan objek lain yang sejenis; 3) relesinya dengan objek lain yang tak sejenis; 4) relasi-dual dengan objek lainnya yang sejenis; 5) relasi dengan objek dalam teori lainnya. ${ }^{3}$

Pemahaman akan tumbuh dan berkembang jika ada proses berpikir yang sistematis dan jelas. Hal-hal yang mempengaruhi terjadinya pemahaman adalah sistematisasi sajian materi, karena materi akan masuk ke otak jika cara masuknya teratur.

Sedangkan konsep menurut ide yang direncanakan dalam pikiran. Konsep menurut Herman adalah suatu ide abstrak yang memungkinkan siswa mengklasifikasikan objek-objek, peristiwa-peristiwa itu termasuk atau tidak kedalam ide abstrak tersebut. ${ }^{4}$ Konsep sebagai suatu abtraksi mental yang memiliki suatu kelas stimulus-stimulus, suatu konsep telah dipelajari bila siswa dapat menampilkan perilaku-perilaku tertentu. Konsep adalah suatu ide abstrak yang memungkinkan orang untuk mengklasifikasikan apakah sesuatu objek tertentu yang merupakan contoh atau bukan contoh dari ide abstrak tersebut.

Dari beberapa pernyataan di atas, dapat dipahami bahwa konsep merupakan ide abstrak yang dapat digunakan untuk menggolongkan atau mengklasifikasikan sekumpulan objek, yang dapat digolongkan sebagai contoh

1 Susanto, A, Teori Belajar dan Pembelajaran di Sekolah Dasar (Jakarta: Kencana Prenada Media Group, 2013), hlm. 208.

${ }^{2}$ Ibid., hlm. 209.

${ }^{3}$ Ibid., hlm. 210.

${ }^{4}$ Herman Hudojo, Pengembangan Kurikulum Dan Pembelajaran Matematika (Malang: Universitas Negeri Malang, 2013), hlm. 124. 
atau bukan contoh. Konsep dalam matematika sebagai gagasan yang bersifat abstrak yang dipahami siswa melalui pengalaman. Konsep juga merupakan dasar berpikir dan belajar tentang aturan dalam matematika. Dimana landasan dasar dari pengetahuan matematika itu sendiri adalah pemahaman konsep.

Pemahaman konsep menurut Hiebert adalah kekuatan yang terkait antara informasi yang terkandung pada konsep yang dipahami dengan skemata yang telah dimiliki sebelumnya. ${ }^{5}$ Rusefendi menyatakan bahwa pemahaman konsep dapat dibagi menjadi dalam tiga aspek yaitu: 1) kemampuan Translation (kemampuan mengubah) soal kata-kata kedalam simbul dan sebaliknya, 2) kemampuan Interpretation (kemampuan mengartikan) suatu kesamaan, 3) kemampuan Ektrapolasi (kemampuan meramalkan) kemampuan mempekirakan suatu kecendrungan diagram. ${ }^{6}$

Konsep-konsep dalam matematika terorganisasi secara matematis, logis, dan hierarkis dari yang paling sederhana ke yang paling kompleks atau dari yang paling kongkrit ke yang paling abstrak. Dengan kata lain, pemahaman dan penguasaan suatu materi atau konsep merupakan prasyarat untuk menguasi materi atau konsep selanjutnya. Oleh sebab itu, dapat dimengerti bahwa kemampuan pemahaman konsep matematis merupakan hal yang sangat fundamental dalam pembelajaran matematika agar belajar menjadi lebih bermakna dan lebih menyenangkan.

Dalam pemahaman konsep siswa dituntut agar dapat mengerti definisi, kaidah, teorema, cara memecahkan masalah dan mengoperasikan matematika secara benar, yang akan menjadi bekal dalam siswa tersebut dalam mempelajari jenjang materi berikutnya, karena itu untuk memahami konsep yang baru perlu bagi seorang siswa untuk pahan pada konsep matematika sebelumnya sebagai prasyarat dalam melanjutkan materinya. Dimana pemahaman akan tumbuh dan berkembang jika ada proses berpikir yang sistematis dan jelas. Hal-hal yang mempengaruhi terjadinya pemahaman adalah sistematisasi sajian materi, karena materi akan masuk ke otak jika cara masuknya teratur.

Selain karena materi matematika yang berprasyarat, kemampuan pemahaman konsep matematis juga erat kaitannya dengan kemampuan pemecahan masalah. Untuk dapat memahami suatu materi dalam belajar matematis, siswa harus mampu menguasai konsep-konsepnya untuk memecahkan masalah yang dihadapi. Untuk mengembangkan kemampuan pemecahan masalah matematik ini tentu harus didukung dengan kemampuan siswa dalam memahami konsep yang berkaitan dalam permasalahan yang akan dipecahkan. Pemahaman konsep menjadi dasar yang cukup penting dalam melakukan pemecahan masalah,

5 Tim PLPG, "Metodologi Pembelajaran Matematika" Modul Pelatihan Pendidikan Guru. (Medan: Jurusan Pendidikan Matematika, Unimed (tidak dipublikasi), 2008), hlm. 42.

6 Ruseffendi, Dasar-dasar Penelitian Pendidikan \& Bidang Non-Eksakta Lainnya (Bandung: Tarsinto, 2005), hlm. 124. 
karena dalam menentukan strategi pemecahan masalah diperlukan penguasaan konsep yang mendasari untuk permasalahan tersebut.

Dengan demikian, dalam pemahaman konsep siswa dituntut untuk mengerti definisi, kaidah, teorema, cara memecahkan masalah dan mengoperasikan matematika secara benar, yang akan jadi bekal dalam mempelajari pada jenjang materi berikutnya, karena untuk memahami konsep yang baru perlu prasyarat pemahaman konsep sebelumnya. Konsep-konsep dalam matematika terorganisasi secra matematis, logis, dan hierarkis dari yang paling sederhana ke yang kompleks atau dari hal yang kongkrit hingga kepada hal yang abstrak. Dengan kata lain, pemahaman dan penguasaan suatu materi atau konsep merupakan prasyarat untuk menguasi materi atau konsep selanjutnya. Oleh sebab itu, dapat dimengerti bahwa kemampuan pemahaman konsep matematik merupakan hal yang sangat fundamental dalam pembelajaran matematika agar belajar menjadi lebih bermakna.

Sebagai indikator bahwa siswa dapat dikatakan paham terhadap konsep matematika, menurut Salami dapat dilihat dari kemampuan siswa dalam beberapa hal sebagai berikut:

1. Mendefinisikan konsep secara verbal dan tulisan.

2. Membuat contoh dan noncontoh penyangkal.

3. Mempersentasikan suatu konsep dengan model, diagram, dan symbol.

4. Mengubah suatu bentuk representasi ke bentuk lain.

5. Mengenal barbagai makna dan interpretasi konsep.

6. Mengidentifikasi sifat-sifat suatu konsep dan mengenal syarat-syarat yang menentukan suatu konsep.

7. Membandingkan dan membedakan konsep-konsep. ${ }^{7}$

Pentingnya pemahaman konsep matemastis tersebut bagi seorang siswa, mengharuskan bagi seorang calon guru dalam hal ini mahasiswa PGMI untuk mengerti dan memahami konsep matematika tersebut, karena di sekolah dasar/ madrasah ibtidaiyahlah pertama sekali konsep matematika itu di ajarkan. Mahasiswa sebagai seorang calon guru benar-benar harus dituntut untuk memiliki pemahaman konsep matematika yang begitu mendalam, karena pemahaman konsep matematis yang dimiliki oleh mahasiswa tersebut, pada masanya nanti pasti akan ditransferkan kepada siswanya kelak. Apabila mahasiswa sebagai calon guru memiliki pemahaman konsep matematis yang mendalam akan suatu topik materi dalam pembelajaran matematika, maka mahasiswa tersebut akan dengan mudah memberikan pemahaman konsep matematika tersebut kepada siswanya ketika belajar matematika dan siswanyapun pasti akan lebih mudah memahami kosep matematika tersebut secara mendalam. Namun sebaliknya, jika mahasiswa sebagai calon guru kurang memiliki pemahaman konsep matematika yang kuat,

\footnotetext{
${ }^{7}$ Op.cit., Susanto, hlm. 209.
} 
maka akan berdapak pada mahasiswa tersebut akan kesulitan untuk menjelaskan dan menanamkan konsep matimatika yang baik, mengakibatkan siswanyapun akan kesulitan untuk memperoleh atau memahami konsep-konsep matematika.

Pentingnya pemahaman konsep matematis tersebut bagi seorang calon guru, membuat peneliti tertarik untuk melalukan penelitian ini. Penelitian ini merupakan hasil tes awal kemampuan mahasiswa dalam memahami konsep bilangan pecahan. Adapun indikator pemahaman konsep matematik yang menjadi rujukan dalam penelitian ini. Adapaun indikator pemahaman konsep matematik dalam penelitian ini meliputi: 1) mendefinisikan konsep, 2) memberikan contoh konsep dan bukan contoh konsep dan 3) mampu menggunakan konsep dalam menyelesaikan masalah. Mampu mendefinisikan konsep dalam penelitian ini diartikan sebagai kemampuan mahasiswa untuk memperoleh makna atau arti ideide abstrak yang dapat digunakan mahasiswa untuk menuliskan definisi konsep bilangan pecahan dengan kata-kata sendiri menurut sifat-sifat/ ciri-ciri yang esensial. Memberikan contoh dan bukan contoh konsep dalam hal ini adalah mahasiswa mampu membedakan antara contoh atau bukan contoh bilangan pecahan. Mampu menggunakan konsep dalam menyelesaikan masalah, dilihat dari bagaimana mahasiswa tersebut dapat memecahkan masalah yang sehari-hari yang diberikan dalam bentuk soal cerita. Hal ini membuat peneliti tertarik untuk menganalis kemampuan pemahaman konsep matematis mahasiswa PGMI pada mata kuliah kajian matematika kelas rendah MI/SD di IAIN Padangsidimpuan. Selain dari lokasi penelitian, materi pada penelitian ini juga berbeda dengan penelitian terdahulu yaitu tentang bilangan pecahan.

\section{B. METODE}

Penelitian ini menggunakan pendekatan kualitatif dengan jenis penelitian diskriptif. Penelitian kualitatif merupakan penelitian yang berfokus untuk mendeskripsikan serta menganalisis tentang fenomena, peristiwa, aktivitas sosial, kepercayaan, sikap, persepsi, pemikiran seseorang baik secara individual maupun kelompok. ${ }^{8}$ Tujuan penelitian ini untuk menganalisis kemampuan pemahaman konsep matematis mahasiswa PGMI pada mata kuliah kajian matematika kelas rendah $\mathrm{MI} / \mathrm{SD}$.

Penelitian ini dilakukan pada mahasiswa PGMI semester IV tahun akademik 2018/2019. Adapun subjek dalam penelitian ini adalah mahasiswa PGMI-1 sebanyak 34 mahasiswa. Prosedur yang dilakukan dalam penelitian ini dimulai dari pendahuluan, menyusun tes kemampuan pemahaman konsep matematika, mengumpulkan data, menganalisis data dan menarik kesimpulan.

${ }^{8}$ Sukmadinata, N. S, Metode Penelitian Pendidikan (Bandung: Remaja Rosdakarya, 2009), hlm. 209. 
Teknik analisis data yang digunakan dalam penelitian ini adalah terdiri dari mereduksi data, menyajikan data, dan menarik kesimpulan. Bentuk data utama yang diperoleh dalam penelitian ini adalah hasil pekerjaan mahasiswa dalam menjawab soal tes uraian tertulis mengenai bilangan pecahan, data tersebut akan direduksi. Hal ini diartikan sebagai kegiatan yang terkait dengan menyeleksi, menyederhanakan, mengelompokkan, memfokuskan, semua data yang telah diperoleh dari hasil tes jawaban siswa. Tahap selanjutnya adalah peneliti menyajikan data yang merupakan hasil reduksi yaitu data berupa deskripsi hasil pekerjaan siswa pada soal tes tertulis. Kemudian kegiatan yang terkhir dalam tahap ini adalah penarikan kesimpulan dari data yang telah diperoleh berdasarkan hasil dari tes jawaban siswa terhadap soal yang telah diberikan.

\section{HASIL DAN PEMBAHASAN}

Berdasarkan hasil tes jawaban mahasiswa terhadap soal kemampuan pemahaman konsep matematis pada materi bilangan pecahan yang dianalisis, diperoleh fakta bahwa kemampuan pemahaman konsep matematis yang dimiliki subjek dalam hal ini adalah mahasiswa PGMI-1 semester IV tahun akademik 2018/2019 masih tergolong rendah. Rendahnya kemampuan pemahaman konsep matematis mahasiswa tersebut yang peneliti peroleh, ditunjukkan dari hasil pekerjaan mahasiswa dalam menjawab soal pemahaman konsep matematis materi bilangan pecahan.

Dari tiga soal tes kemampuan pemahaman konsep matematis yang diberikan oleh peneliti, masih banyak hasil jawaban yang diberikan mahasiswa belum dapat memberi jawaban yang benar sesuai dengan pertanyaan pada soal sehingga jawaban yang mahasiswa berikan menggambarkan masih rendahnya pemahaman konsep matematis yang dimiliki oleh mahasiswa pada materi bilangan pecahan. Dari hasil pengumpulan data diperoleh fakta bahwa untuk soal nomor satu, dimana peneliti ingin mengukur kemampuan pemahaman konsep matematis mahasiswa dengan menggunakan indikator mampu menjelaskan sebuah defenisi dari bilangan pecahan dengan kata-kata sendiri menurut sifatsifat/ciri-ciri yang esensial. Dari 34 mahasiswa, hanya ada 16 mahasiswa yang dapat mendefinisikan bilangan pecahan dengan benar, selebihnya salah dalam mendefinisikan bilangan pecahan. Dan untuk soal nomor dua, yaitu peneliti ingin mengukur kemampuan pemahaman konsep matematis mahasiswa dengan indikator mampu membrikan/membedakan contoh dan bukan contoh bilangan pecahan, dari 34 mahasiswa hanya 10 mahasiswa yang mampu membedakan contoh bilangan pecahan dan bukan bilangan pecahan dengan benar. Selanjutnya pada soal nomor tiga yang bertujuan untuk mengukur kemampuan pemahaman konsep matematis mahasiswa dengan indikator mampu menggunakan/mengaplikasikan konsep bilangan pecahan dalam permasalah- 
permasalahan matematika, hanya 12 mahasiswa mampu menggunakan/mengaplikasikan konsep bilangan pecahan untuk memecahkan masalah dalam kehidupan sehari-hari, selebihnya salah dalam memahami soal sehingga salah dalam menggunakan konsepnya. Berikut ini adalah tabel persentase hasil kerja mahasiswa:

Tabel 1. Hasil Persentase Jawaban Mahasiswa Secara Klasikal

\begin{tabular}{|c|c|c|c|c|}
\hline \multirow{2}{*}{ Jawaban } & \multicolumn{3}{|c|}{ Soal } & Jumlah \\
\cline { 2 - 4 } Rata-rata
\end{tabular}

Keterangan:

Soal No.1 sampai No.3 = Berupa pertanyaan yang berkaitan dengan materi bilangan pecahan.

\section{Analisis Jawaban Mahasiswa Berdasarkan Tes Pemahaman Kosep Matematis}

\section{Soal Nomor 1}

Soal nomor 1 adalah soal yang bertujuan untuk mengukur kemampuan mahasiswa dalam mendefinisikan konsep bilangan pecahan dengan kata-katanya sendiri menurut sifat-sifat/ ciri-ciri yang esensial. Berdasarkan tabel persentse di atas, dapat diketahui bahwa 47,06 \% atau sebanyak 16 mahasiswa mampu mendefinisikan bilangan pecahan dengan benar. Dan 18 mahasiswa atau sebesar $52,94 \%$ mahasiswa tidak mampu mendefinisikan bilangan pecahan dengan benar. Adapun hasil kerja pemahaman konsep matematis mahasiswa dalam mendefinisikan bilangan pecahan dapat dilihat berikut ini:

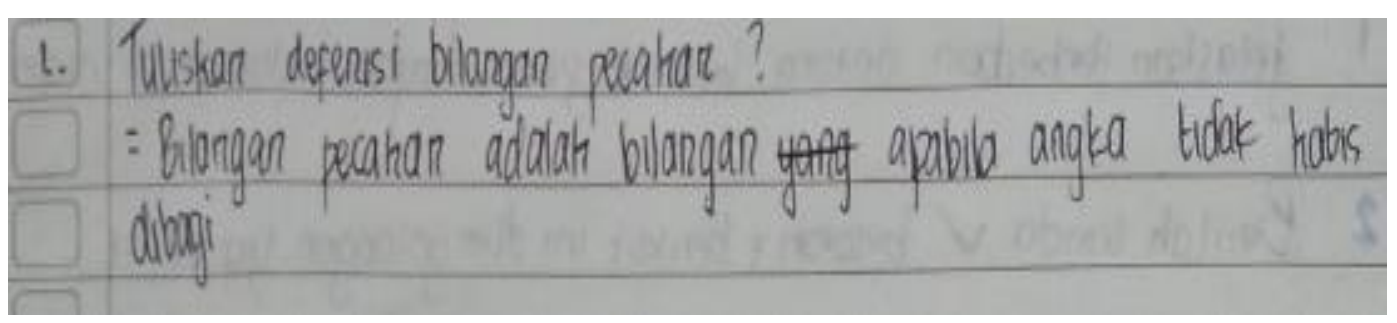

(a) 


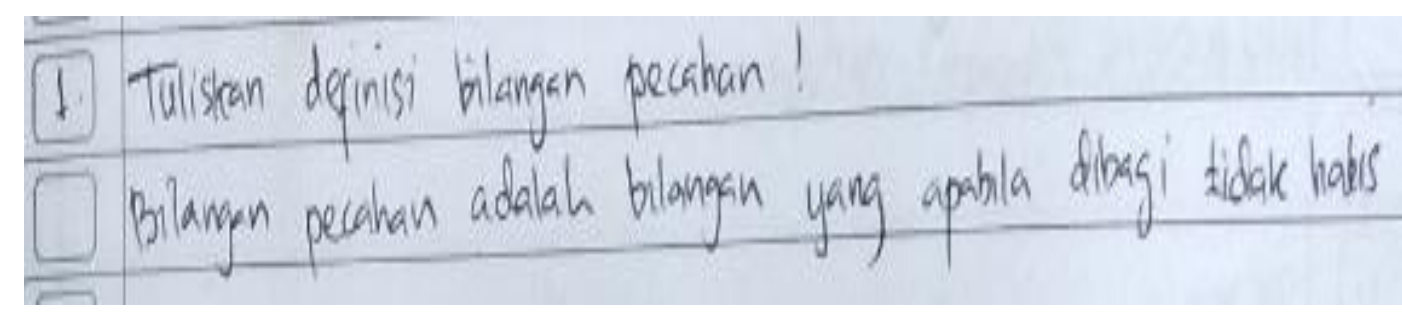

(b)

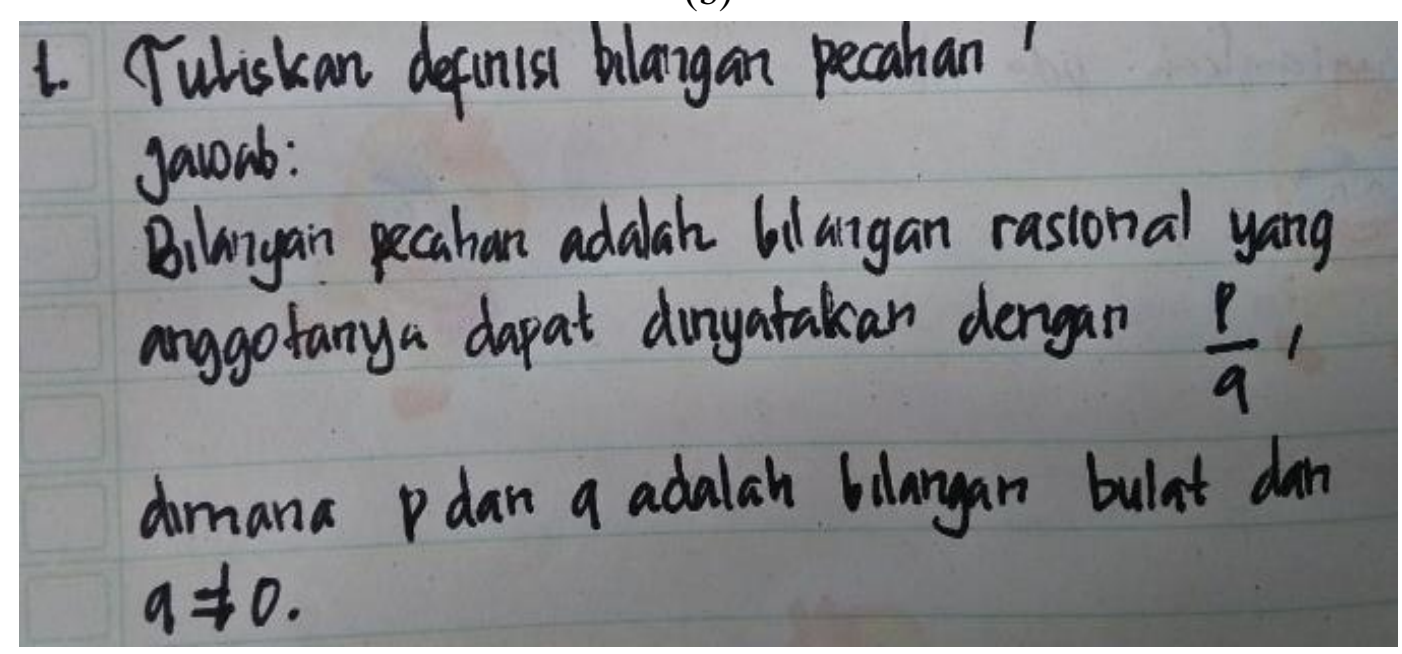

(c)

Gambar 1. Hasil Pekerjaan Mahasiswa tentang Definisi Pecahan

Jawaban mahasiswa tentang mendefinisikan bilangan pecahan pada Gambar 1a adalah contoh jawaban mahasiswa yang tidak benar dalam mendefinisikan bilangan pecahan. Pada Gambar 1b adalah contoh jawaban mahasiswa yang yang hampir benar dalam mendefinisikan bilangan pecahan, Sedangkan pada Gambar 1c adalah jawaban mahasiswa yang benar dalam mendefinisikan bilangan pecahan. Pada Gambar 1a, dapat di analisis bahwa maksud dari yang dituliskan mahasiswa tidak jelas sehingga definisi yang dia maksudkan tidak dimengerti atau tidak benar sehingga dapat dimengerti bahwa pada Gambar 1a menunjukkan bahwa mahasiswa tersebut tidak memahami apa yang dimaksud dengan bilangan pecahan sehingga definisi yang diberikan tidak tepat. Kemudian pada Gambar 1b menunjukkan bahwa mahasiswa tersebut kurang mampu memahami apa itu bilangan pecahan sehingga definisi yang diberikan kurang tepat. Mahasiswa tersebut hanya menyebutkan bilangan yang tidak habis dibagi, tanpa memberikan syarat dari penyebut. Gambar 1c menunjukkan mahasiswa sudah mampu memahami bilangan pecahan sehingga mampu mendefinisikannya dengan jelas dan benar. Mahasiswa tersebut mampu mendefinisikan bilangan pecahan dengan kata-katanya sendiri, berdasarkan sifat/ ciri bilangan pecahan tersebut, yaitu bilangan yang berbentuk $\frac{p}{q}$ dimana $p$ dan $q$ adalah bilangan bulat, dan $q \neq 0$. 


\section{Soal Nomor 2}

Soal nomor 2 adalah soal yang bertujuan utnuk mengukur kemampuan mahasiswa dalam menuliskan/ membedakan contoh dan bukan contoh bilangan pecahan berdasarkan konsep pecahan yang diketahuinya menurut pemahamannnya sendiri serta memberikan alasan mengapa mahasiswa tersebut menyebutkan bilangan ini termasuk bilangan pecahan atau bukan pecahan. Berdasarkan Tabel 1 di atas, diketahui bahwa hanya 10 mahasiswa atau 29,41\% mahasiswa mampu menuliskan/ membedakan contoh dan bukan contoh pecahan serta alasan mampu memberikan alasannya dengan benar dan sebesar 70,59\% atau sebanyak 24 mahasiswa tidak mampu membedakan contoh dan bukan contoh bilangan pecahan serta tidak dapat memberikan alasan yang benar mengapa contoh tersebut dikatakan bilangan pecahan atau bukan pecahan. Hal ini dapat dilihat dari ragam jawaban mahasiswa berikut ini:

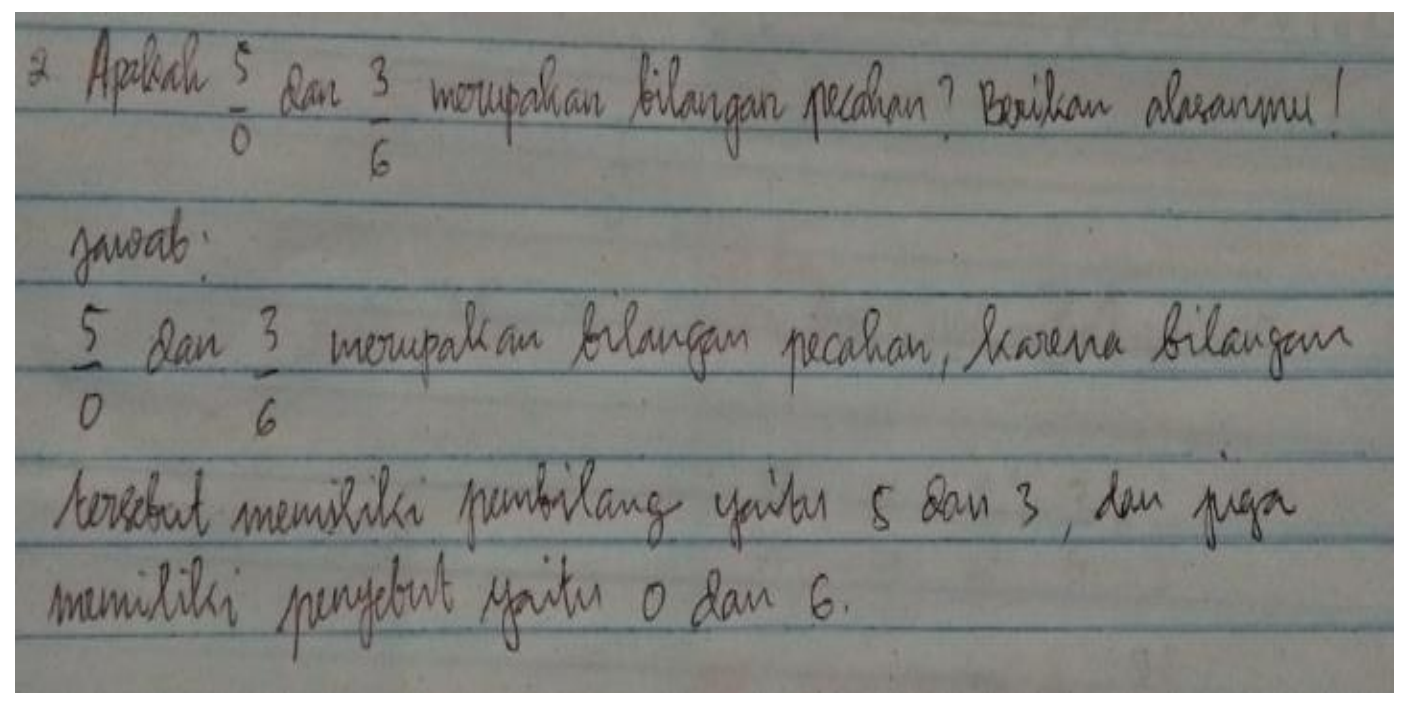

(a)

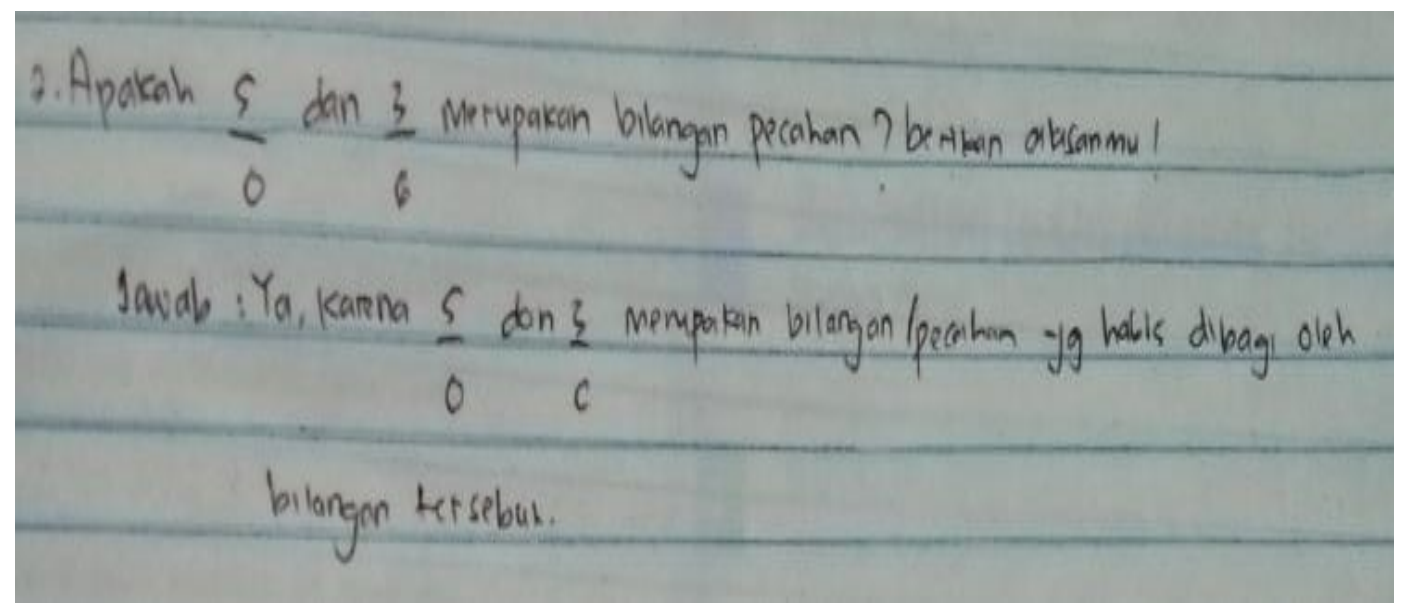

(b) 


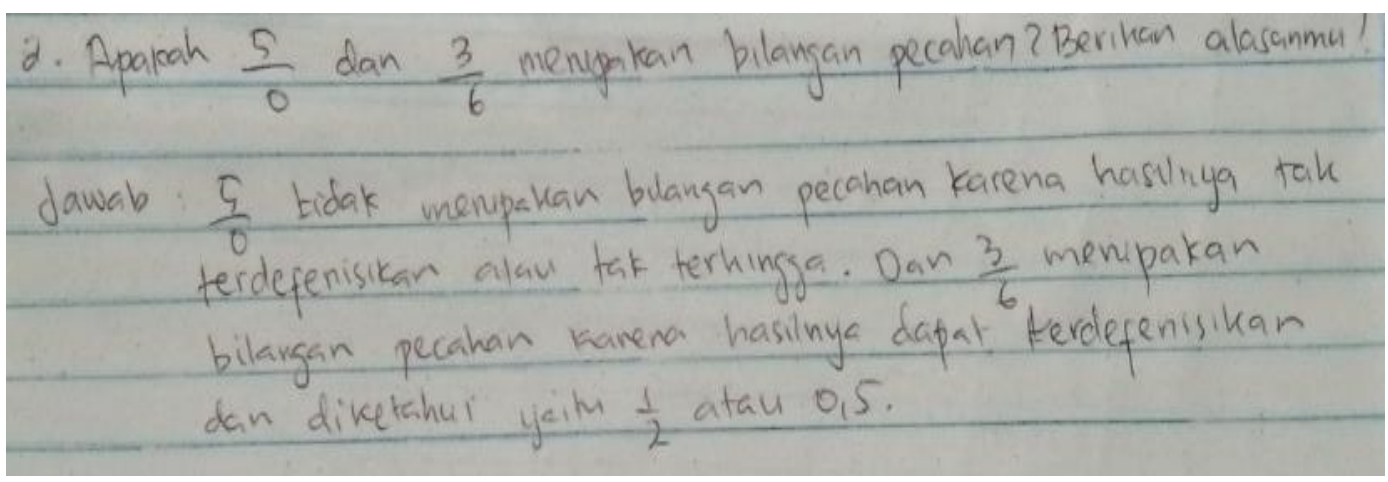

(c)

Gambar 2. Jawaban Mahasiswa tentang Contoh dan Bukan Contoh Bilangan Pecahan

Pada Gambar 2a dapat dianalis, jawaban mahasiswa tersebut masih kurang tepat. Karena mahasiswa hanya mengetahui bentuk umum dari bilangan pecahan, yaitu memiliki penyebut dan pembilang tanpa mengetahui syarat dari pembilang dan penyebut tersebut, yaitu penyebut dan pembilang adalah bilangan bulat dan penyebut harus merupakan bilangan asli atau tidak sama dengan nol. Kemudian pada Gambar 2b jawaban mahasiswa juga salah. Mahasiswa tersebut jelas sekali tidak paham definisi bilangan pecahan dan tidak paham apa yang dimaksud dengan habis dibagi. Jawaban mahasiswa tersebut jelas merupakan jawaban yang keliru. Karena $\frac{5}{0}$ dan $\frac{3}{6}$ bukanlah bilangan yang habis dibagi. Sedangkan pada Gambar 2c di atas dapat dilihat bahwa mahasiswa sudah mampu memberikan contoh dan bukan contoh dari bilangan pecahan dengan benar. Mahasiswa mampu memberikan sendiri baik contoh ataupun bukan contoh dari bilangan pecahan berdasarkan pemahamannya sendiri.

\section{Soal Nomor 3}

Soal nomor 3 ini adalah soal yang bertujuan untuk mengukur dan mengetahui tingkat pemahaman konsep mahasiswa terhadap pengaplikasian konsep bilangan pecahan dalam kehidupan sehari-hari. Seberapa mampukah mahasiswa tersebut menggunakan konsep pecahan yang dia ketahui dalam memecahkan persoalan -persoalan sehari-hari yang mengaitkan bilangan pecahan tersebut. Dan bagaimana mahasiswa tersebut merubah soal cerita ini menjadi model matematika menurut konsep-konsep bilangan pecahan yang diketahuinya, sehingga menunjukkan seberapa tepat mahasiswa mampu menggunakan konsep bilangan pecahan tersebut dalam menyelesaikan soal cerita di dalam kehidupan nyata. Berdasarkan Tabel 1 di atas, dapat dilihat bahwa hanya 12 mahasiswa atau sebesar 32,29 \% mahasiswa yang mampu dengan benar menggunakan konsep bilangan pecahan yaitu dengan cara merubah soal cerita kedalam model matematika untuk menyelesaikan masalah sehari-hari. Dan 22 mahasiswa atau sebesar $64,71 \%$ tidak mampu mampu menggunakan konsep pecahan untuk 
menyelesaikan masalah matematika tersebut. Hal ini dapat dilihat dari hasil kerja mahasiswa berikut ini:

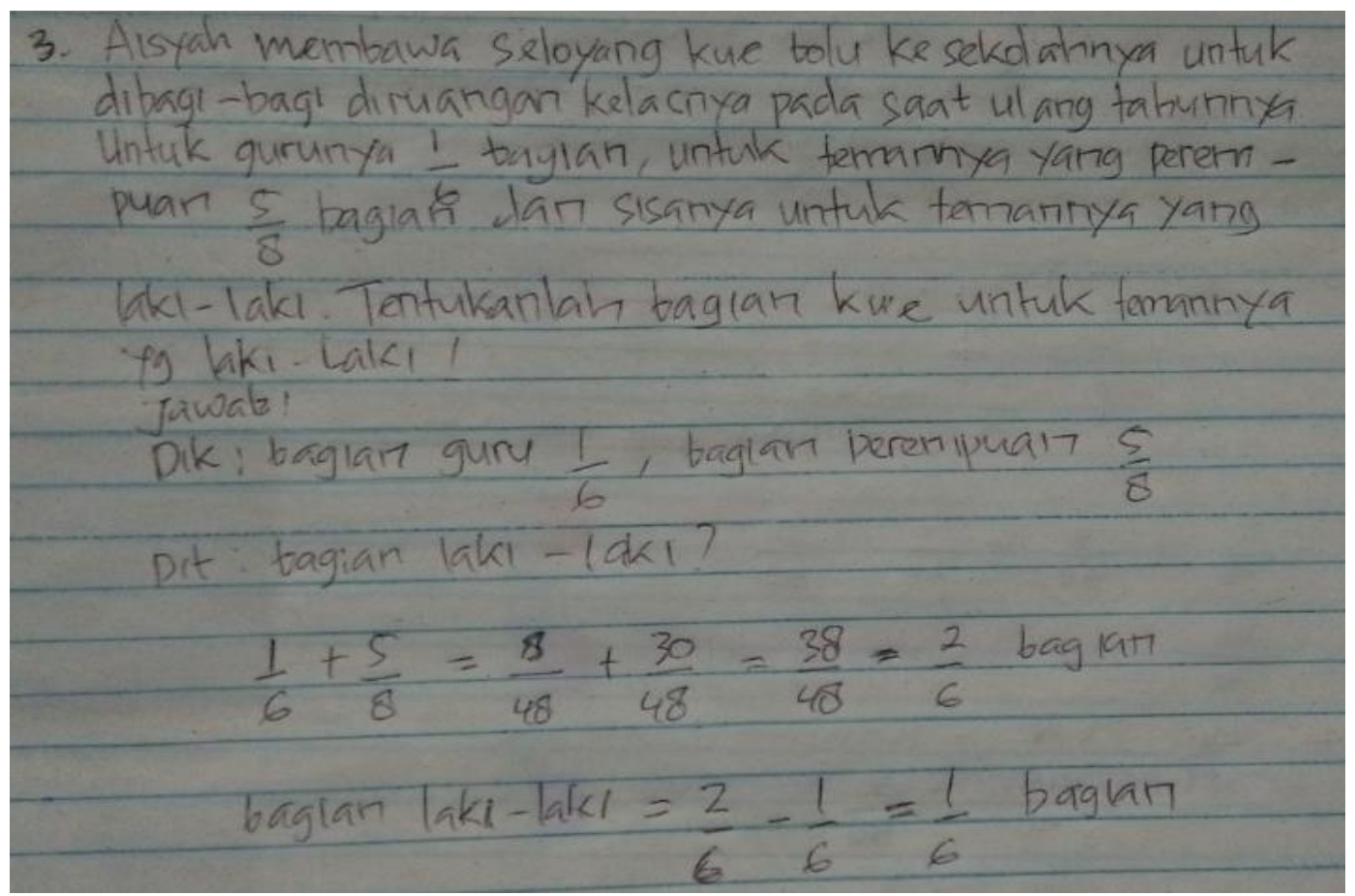

(a)

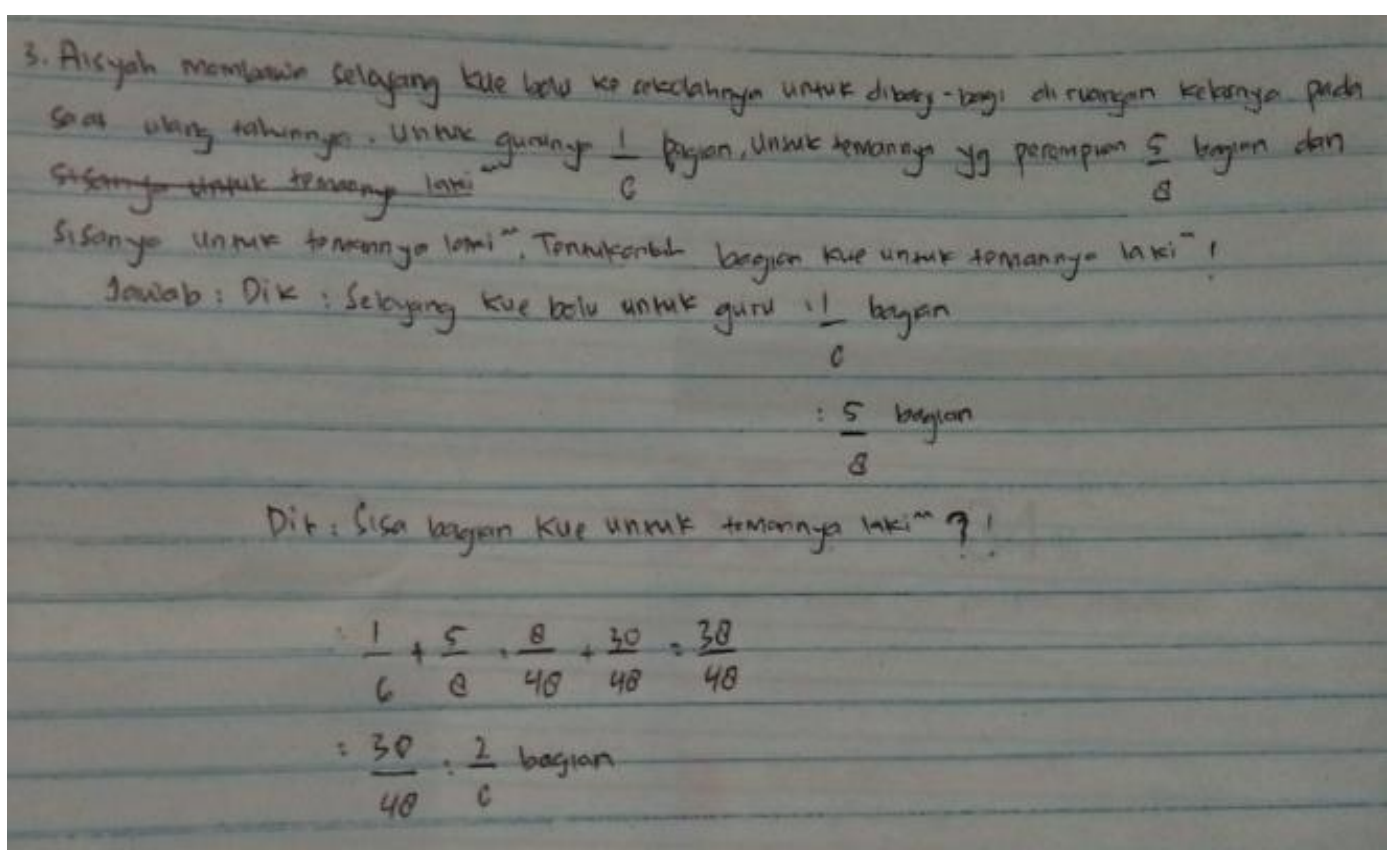

(b) 


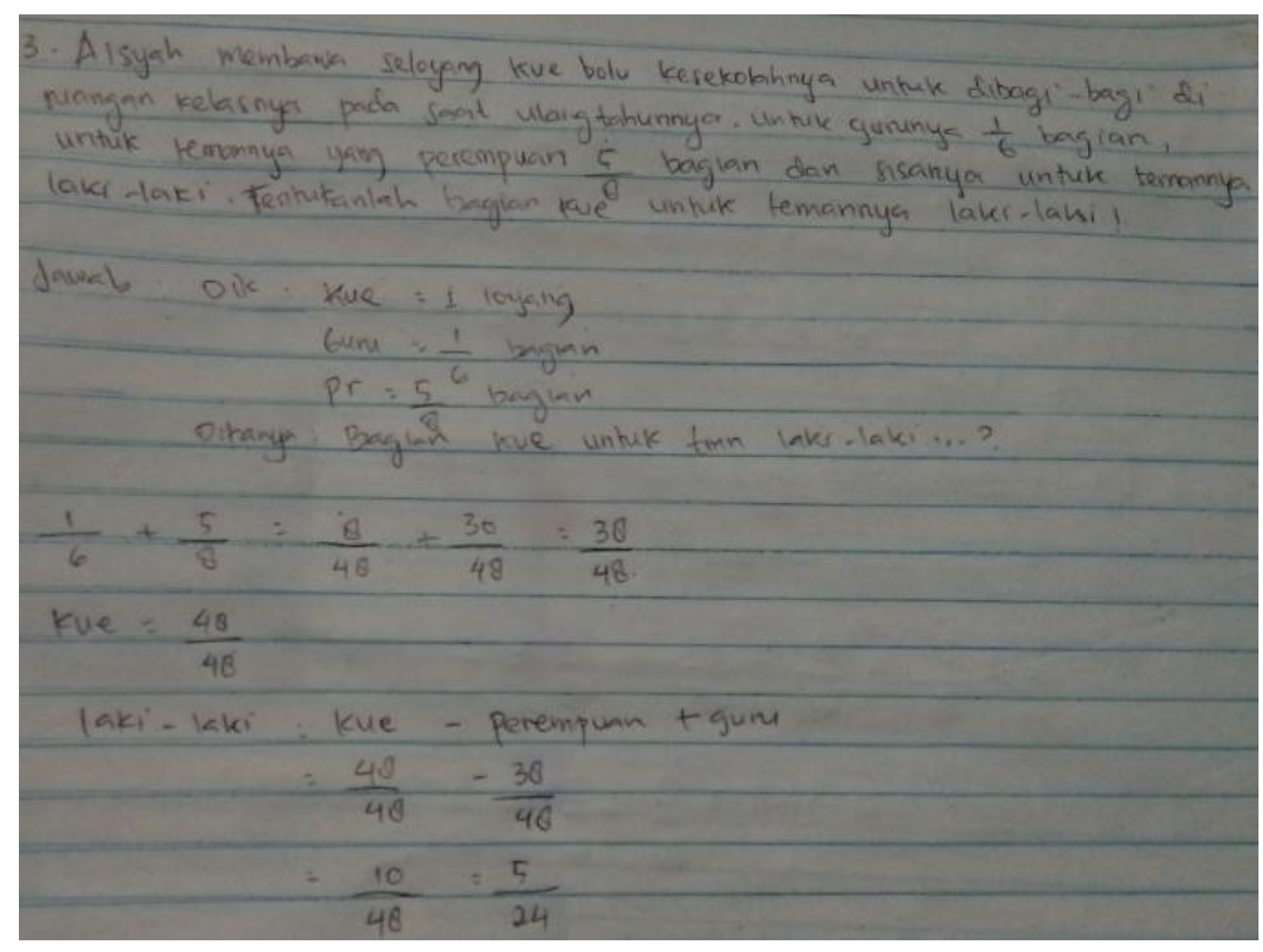

(c)

Gambar 3. Hasil Pekerjaan Mahasiswa

Pada Gambar 3a, jawaban mahasiswa membingungkan. Setengah jalan jawabannya sudah benar yaitu dengan menjumlahkan bagian guru dengan bagian teman yang perempuan yaitu $\frac{1}{6}+\frac{5}{8}=\frac{8+30}{48}=\frac{38}{48}$ namun salah dalam mengecilkan bilangan. Tapi yang paling membingungkan darimana angka $\frac{1}{6}$ pada penyelesaian $\frac{2}{6}-\frac{1}{6}=\frac{1}{6}$. Ini jelas menunjukkan bahwa mahasiswa tersebut kurang paham definisi bilangan pecahan, sehingga kurang mampu merubah soal cerita tersebut ke dalam model matematika. Hal ini menunjukkan bahwa mahasiswa tersebut kurang mampu mengaplikasikan kosep bilangan pecahan pada kehidupan seharihari. Kemudian untuk Gambar 3b ini, jawaban mahasiswa tidak benar. Mahasiswa baru menyelesaikan setengah jalan, tetapi sudah langsung menyimpulkan bahwa hasil tersebut merupakan sisa kue bolu/ bagian temannya yang laki-laki. Ini menunjukkan, jelas sekali bahwa mahasiswa tersebut kurang mampu memahami konsep atau lemah dalam mendefinisikan konsep, yaitu definisi bilangan pecahan, sehingga tidak mampu menggunakan konsep bilangan pecahan untuk memecahankan masalah tersebut. Sedangkan Gambar 3c menunjukkan mahasiswa mampu manggunakan konsep bilangan pecahan dalam memecahkan soal cerita yang menyangkut kehidupan sehari-hari tersebut. Hal ini menunjukkan mahasiswa tersebut paham definisi bilangan pecahan, sehingga mampu mengaplikasikannya dalam pemecahan masalah. 
Berdasarkan analisis jawaban mahasiswa tersebut di atas, dapat dimengerti bahwa kemampuan pemahaman konsep matematis mahasiswa PGMI semester IV masih rendah. Sekalipun penelitian ini memiliki hasil yang sama dengan penelitian Melinda Rismawati,dkk dimana di dalam penelitiannya menunjukkan bahwa kemampuan mahasiswa dalam memahami konsep matematika masih tergolong rendah terbukti dari persentase ketercapaian tiap indikator yang masih rendah, ${ }^{9}$ akan tetapi memiliki perbedaan. Dan terhadap penelitian Cita Dwi Rosita, dkk juga berbeda. Dimana dalam penelitian Cita Dwi Rosita, dkk disimpulkan Kemampuan pemahaman matematis mahasiswa secara klasikal tidak mencapai ketuntasan artinya nilai rata-rata semua mahasiswa berada di bawah KKM yang ditentukan yaitu $65 .^{10}$ Perbedaan penelitian ini antara lain ialah memiliki subjek dan materi yang berbeda serta lokasi penelitian yang berbeda.

\section{KESIMPULAN}

Berdasarkan dari hasil analisis data dan pembahasan di atas, maka dapat disimpulkan bahwa kemampuan pemahaman konsep matematis mahasiswa PGMI-1 masih tergolong rendah baik dalam hal mendefinisiskan bilangan pecahan, dalam membuat/ menyebutkan contoh dan bukan contoh bilangan pecahan serta rendah dalam mengaplikasikan konsep bilangan pecahan terhadap masalah dalam kehidupan sehari-hari. Hal ini dibuktikan dengan hasil tes kemampuan pemahaman konsep matematis bahwa rata-rata mahasiswa yang mengerjakan soal dengan benar sebesar 33,25 \% dan rata-rata mahasiswa yang mengerjakan soal dengan salah sebesar $62,75 \%$. Kesalahan paling banyak terdpat pada soal nomor 2 dan 3, karena lebih dari setengah jumlah mahasiswa diruangan tidak mampu menjawab soal dengan benar.

Hasil dari penelitian ini dapat dijadikan sebagai informasi kepada para dosen mengenai kemampuan pemahaman konsep matematis yang dimiliki mahasiswa dalam mempelajari matematika. Karena pemahaman konsep sangat penting dalam mempelajari matematika. Oleh karenanya peneliti menyerakan: (1) bagi peneliti selanjutnya, agar menngunakan lebih banyak lagi indikator pemahaman konsep matematika dari para ahli pada materi yang berbeda dengan penelitian ini, (2) hendaknya peneliti selanjutnya dapat mengembangkan/ merancang pembelajaran yang dapat digunakan untuk meningkatkan kemampuan pemahaman konsep matematis mahasiswa, khususnya mahasiswa PGMI sebagai calon guru SD/MI.

\footnotetext{
${ }^{9}$ Melinda Rismawati, Anita Sri Rejeki Hutagaol. Jurnal Pendidikan Dasar PerKhasa, Vol 4. No, 1 April 2018, hlm. 91.

${ }^{10}$ Cita Dwi Rosita, Laelasari, dan M. Subali Noto. Jurnal Euclid, vol.1, No.2, 2014, hlm. 68.
} 


\section{DAFTAR PUSTAKA}

Cita Dwi Rosita, Laelasari, dan M. Subali Noto. Jurnal Euclid, vol.1, No.2, 2014.

Herman Hudojo, Pengembangan kurikulum Dan Pembelajaran Matematika, Malang: Universitas Negeri Malang, 2013.

Melinda Rismawati, Anita Sri Rejeki Hutagaol. Jurnal Pendidikan Dasar PerKhasa, Vol 4. No, 1 April 2018.

Ruseffendi. Dasar-dasar Penelitian Pendidikan \& Bidang Non-Eksakta Lainnya, Bandung: Tarsinto, 2005.

Sukmadinata, N. S, Metode Penelitian Pendidikan. Bandung: Remaja Rosdakarya, 2009.

Susanto, A, Teori Belajar dan Pembelajaran di Sekolah Dasar, Jakarta: Kencana Prenada Media Group, 2013.

Tim PLPG, "Metodologi Pembelajaran Matematika” Modul Pelatihan Pendidikan Guru. Medan: Jurusan Pendidikan Matematika, Unimed, (tidak dipublikasi), 2008. 